\title{
Impact of grazing regime on a Mongolian forest steppe
}

\author{
Van Staalduinen, Marja A.*; During, Heinjo \& Werger, Marinus J.A. \\ Department of Plant Ecology, Utrecht University, P.O. Box 800.84, NL-3508 TB Utrecht, The Netherlands; \\ *Corresponding author; Tel. +31 302536839; Fax+31 302538366; E-mailm.a.vanstaalduinen@bio.uu.nl
}

\begin{abstract}
Question: What is the impact of grazing regime on plant species abundance, plant growth form, plant productivity and plant nutrient concentrations in a forest steppe?

Location: Hustai National Park in the forest steppe region of Mongolia.

Methods: On the Stipa steppe we applied three different grazing regimes by using; (1) one type of exclosure which excluded grazing by large mammalian herbivores, mainly takh (Przewalski horse), (2) another type of exclosure that excluded both large and small (Siberian marmots) mammalian herbivores, and (3) control plots which were freely grazed. We measured species frequencies, tiller densities, plant biomass and nitrogen concentrations of the vegetation.

Results: Exclusion from grazing by takh and marmots significantly increased plant standing crop, but marmot grazing and full grazing did not show significant differences. Protection from grazing decreased forage quality, shown by a lower $\mathrm{N}$ concentration of the standing crop. However, this was solely the result of the lower live-dead ratio of the vegetation. The frequency of the rhizomatous Leymus chinensis decreased under reduced grazing, as did the frequency of the total of rhizomatous species. The frequency of Stipa krylovii increased under reduced grazing, as did its basal areas, tiller density and tussock height.

Conclusion: Reduced grazing leads to a lower abundance of rhizomatous species and an increase in tussock species.
\end{abstract}

Keywords: Equus przewalskii; Grassland; Grazing intensity; Growth form; Leymus chinensis; Nutrient concentration; Rhizomatous species; Species composition; Stipa krylovii; Takh.

Nomenclature: Grubov (2001).

Abbreviations: $\mathrm{BA}=$ Basal area DCA $=$ Detrended Correspondence Analysis; PRC = Principal Response Curve.

\section{Introduction}

Mammalian herbivores play a crucial role in the sustainability of natural grasslands through their influence on the structural and functional properties of the ecosystem (Bakker et al. 1983; Detling 1998; Werger et al. 2002). On the semi-arid steppes of Mongolia there is a long history of grazing by large herbivores. In the forest steppe region, the vegetation of the typical Stipa steppe comprises of grasses that grow in tussocks, such as the caespitose Stipa krylovii, and grasses that grow with tillers along rhizomes such as Leymus chinensis (Elymus chinensis, Grubov 2001). See Hilbig (1995); Wallis de Vries et al. (1996).

In studies on the vegetation of the Stipa steppe, Hilbig (1995), Fernandez-Gimenez \& Allen-Diaz (2001), Gunin et al. (1999) and Xie \& Wittig (2003) observed that the caespitose Stipa is dominant at sites with a low or moderate grazing intensity, while at higher grazing intensity the rhizomatous Leymus chinensis and Carex duriuscula are more abundant. Hilbig (1995) distinguished two major subassociations and two grazing facies within the typical Stipa steppe. The Arctogeron gramineum subassociation occurs on exposed stony and rocky sites with a thin soil, while the Galium verum subassociation occurs on less dry sites and contains many species that are also found in the meadow steppe (Hilbig 1995). Under moderate grazing species of the typical Stipa steppe occur, such as Stipa krylovii, Agropyron cristatum, Poa attenuata, Potentilla acaulis and Cymbaria dahurica (grazing facies 1). Under severe grazing Stipa krylovii is replaced by Leymus chinensis and species such as Cleistogenes squarrosa, Carex duriuscula and Artemisia adamsii (grazing facies 2) become dominant (Hilbig 1995). Comparable observations were made in European grasslands (Pakeman 2004) and in the North American prairies; the originally dominant tussock species were replaced by rhizomatous species when grazing pressure increased (Milchunas et al.1988; Mack \& Thompson 1982).

These findings suggest a higher grazing tolerance of the rhizomatous species. This could be due to the occurrence of compensatory growth, which might mitigate the potential negative effects of defoliation (Anten et al. 
2003). In a greenhouse experiment Leymus chinensis indeed had a much stronger compensatory growth after clipping than Stipa krylovii (van Staalduinen \& Anten 2005, see also Wang et al. 2004). The decline in tussock grasses after grazing could be due to fragmentation of individual plants; in the tussock grass Schizachyrium scoparium Butler \& Briske (1987) found a reduction in plant basal areas and decreased tiller densities in response to herbivory.

In plants grazed by herbivores the nitrogen concentration of the shoots often increases with the intensity of grazing and with different types of grazing (Bakker et al. 1983; Detling 1999; Holland et al. 1992; Oesterheld 1992). Differences in forage preference and grazing habit between large and small mammals have different effects on vegetation structure and composition and plant nutrient concentrations (Detling 1998; Olff \& Ritchie 1998).

In studies on Mongolian steppes, differences in food preference between takh (Przewalski horse) and marmots have been reported (Anon. 1998-2001). We conducted an exclosure experiment on the Stipa steppe in Mongolia in which we examined the effects of three years exclusion of takh (Equus przewalskii) and Siberian marmot (Marmota sibirica) on plant species abundance, growth form, plant biomass and plant $\mathrm{N}$-concentration. We address the following questions: if grazing of marmots or of marmots and takh is excluded, (1) does the abundance of rhizomatous species, and specifically Leymus chinensis, decrease; (2) does the abundance of tussock species, and specifically Stipa krylovii, increase; (3) is there a decreased fragmentation of the tussocks of Stipa krylovii; (4) do the shoots have a lower N-concentration?

\section{Methods}

\section{Experimental site}

An exclosure experiment was carried out in Hustai National Park, $100 \mathrm{~km}$ west of Ulaan Baatar, Mongolia $\left(47^{\circ} 50^{\prime} 2^{\prime \prime} \mathrm{N}, 106^{\circ} 00^{\prime} 2^{\prime \prime} \mathrm{E}\right)$. In Mongolia the climate is arid and continental (mean annual temperature $+2{ }^{\circ} \mathrm{C}$ ), with a short growing season in summer (from June to September) in which most of the precipitation falls (annual precipitation $296 \mathrm{~mm}$ in Hustai National Park). 2002 was a very dry year with a total precipitation of $166.9 \mathrm{~mm}$ and summer precipitation (May - September) of $111.0 \mathrm{~mm}$. 2003 was a wet year with $334.9 \mathrm{~mm}$ total precipitation and $166.9 \mathrm{~mm}$ summer precipitation (Anon. 2000-2002, 2003).

Hustai National Park, situated in the forest steppe region of Mongolia, occupies 60000 ha at elevations ranging from 1100 to $1840 \mathrm{~m}$ a.s.l. Ca. $88 \%$ of the area is covered by grassland and shrub steppe and ca. $5 \%$ by birch-dominated forest. Native ungulates are free-ranging within the park and include takh (Equus przewalskii), red deer (Cervus elaphus), wild boar (Sus scrofa), roe deer (Capreolus capreolus), migrating Argali sheep (Ovis ammon) and Mongolian gazelle (Procapra gutturosa). The park also contains abundant populations of the Siberian marmot (Marmota sibirica), an important rodent herbivore. Takh was re-introduced in Hustai National Park in 1992.

A widespread grassland type in the park is the Stipa steppe, classified as the Thermopsis lanceolata-Stipa krylovii community (Wallis de Vries et al. 1996), and dominated by Stipa krylovii, while Thermopsis lanceolata, Poa attenuata and Koeleria macrantha are characteristic species of this community on kastanozems (dark brown soils). The vegetation cover ranges from 45 to $90 \%$ with an average of $70 \%$. Sites where the grazing intensity was rather high at the beginning of the experiment were selected using monitoring data of the takh and the Siberian marmots (Anon. 1998-2001).

\section{Design}

In June 2000, exclosures were built at four locations on the Stipa steppe. All were chosen within the home-ranges of takh harems (areas where they generally graze) and within the main local distribution area of the marmots. Treatments were: ungrazed (exclusion of both takh and Siberian marmots), marmot-grazed (exclusion of takh only) and fully grazed (control). For each treatment there were four replicates per location, which makes 12 plots on each location. Within a location, four transects at different elevations were selected at regular distances, and on each transect the treatments were distributed randomly.

The exclosures were constructed with fences made of mesh wire (mesh size of $4 \mathrm{~cm}$ ), and barbed wire around a $4 \mathrm{~m} \times 4 \mathrm{~m}$ plot. Ungrazed plots were surrounded by a fence of $1.5 \mathrm{~m}$ high and the marmot-grazed plots by a fence of $1.5 \mathrm{~m}$ high, but open from 0 to $30 \mathrm{~cm}$ above the ground. The fully grazed plots had no fence. By excluding the takh and marmots, other large and small mammalian herbivores of the same size were excluded as well. Smaller rodents, like Brandt's vole (Lasiopodomys brandtii), Microtus brandtii and M. fortis were able to pass the mesh wire.

To estimate grazing intensity of the takh at the different locations we counted dung droppings on a $10 \mathrm{~m}$ $\times 40 \mathrm{~m}$ plot established in between the exclosure plots. The droppings of the takh, and occasionally of deer and cows, were counted and marked by painted sticks. After ca. 30 days the new droppings were counted and painted (during dry periods, the interval was 8 to 10 weeks). Lo- 
cation 3 (37.1 droppings) had a higher grazing intensity than location 1 (17.8 droppings) and 4 (15.1 droppings). Between locations 1,2 (23.2 droppings) and 4 there was no significant difference in grazing intensity (ANOVA with location as factor).

\section{Sampling}

In the last two weeks of July 2002 and 2003, the above-ground biomass was sampled by clipping a $50 \mathrm{~cm}$ $\times 1 \mathrm{~m}$ strip in each of the plots (every year a different strip was clipped). The vegetation was clipped at ground level and sorted to standing live biomass, standing dead biomass, and litter. The standing crop, being the sum of standing live and standing dead biomass, was determined as it is the forage herbivores graze on. The plants were dried in an oven at $70{ }^{\circ} \mathrm{C}$ for $48 \mathrm{~h}$ and weighed.

In July 2003 also the below-ground biomass was sampled by taking root cores, $7.9 \mathrm{~cm}$ in diameter and $12 \mathrm{~cm}$ deep, at three random locations along each strip immediately after clipping. These cores were washed over a $2 \mathrm{~mm}$ mesh screen to remove soil and dead or decayed material. After drying of all live material (roots and rhizomes combined) at $70{ }^{\circ} \mathrm{C}$ for $48 \mathrm{~h}$, dry weight was determined.

To determine soil characteristics soil cores with a diameter of $2.8 \mathrm{~cm}$ and $7 \mathrm{~cm}$ deep were taken in 2003 . Below-ground plant parts were removed and the soil was oven dried at $70{ }^{\circ} \mathrm{C}$ for $48 \mathrm{~h}$. Total organic nitrogen concentrations in the standing live biomass, standing dead biomass, litter, roots and soil were determined after Kjeldahl digestion using a continuous flow analyzer (SKALAR, Breda, The Netherlands).

In the first half of July 2002 basal areas and tiller densities of Stipa tussocks were determined in a $1-\mathrm{m}^{2}$ plot inside each of the $4 \mathrm{~m} \times 4 \mathrm{~m}$ plots of the ungrazed treatment and fully grazed treatment. The diameter of each tussock was measured in two directions and used for calculating the basal area, assuming an ellipse shape of the tussock. In a $2 \mathrm{~cm}$ wide strip in the centre of the tussock the number of live tillers was counted and the tiller density per $\mathrm{cm}^{2}$ determined. The number of tillers per tussock was estimated by multiplying the tiller density by the basal area of the tussock.

In a $1-\mathrm{m}^{2}$ permanent plot inside the exclosure and control plots measurements of species frequencies were taken once in the growing season in the second and third week of August 2001, 2002, and 2003. Using a $1 \mathrm{~m} \times 1$ $\mathrm{m}$ grid divided into $10 \mathrm{~cm} \times 10 \mathrm{~cm}$ sections which was laid on the vegetation, the total number of sections was counted in which a certain species was present. Frequencies of all the species were recorded.

\section{Statistical analysis}

Data were analysed with the statistical package SPSS 10.0 for Windows (SPSS Inc. Chicago, Illinois, USA). A GLM repeated measures was used to analyse the overall effects and the interactions between factors (year $\mathrm{df}=$ 1 , grazing $\mathrm{df}=2$, location $\mathrm{df}=3$ ) on data of biomass, $\mathrm{N}$-concentrations and species frequency. With a post hoc multiple comparison test and a contrasts test, on which a Bonferroni correction was applied, the differences between the means were tested. In cases where data from only one year was available, a one-way ANOVA was used to test the significance of the effect of grazing. With a $\chi^{2}$ test the effect of grazing on size distribution of Stipa tussocks was analysed. Differences were considered significant at $P<0.05$.

To analyse the effects of the grazing treatments on the overall composition of the vegetation, we performed a detrended correspondence analysis (DCA) (untransformed) with species frequency data (2003) (Jongman et al.1995), using the statistical package CANOCO 4.5 (ter Braak \& Šmilauer 2002). A Principal Response Curve analysis (PRC) was first carried out on species to show the change in abundance in the treatments relative to the control. Because the interpretation was difficult, we classified the species into functional and sociological groups. We distinguished the functional groups herb, shrub, cushion growth form, tussock graminoids and rhizomatous graminoids. Based on the phytosociological analysis of the Mongolian steppes by Hilbig (1995), the species were also classified into four sociological groups representing the two major subassociations and two grazing facies of the typical Stipa steppe described before.

We constructed a matrix of samples against the functional and sociological groups (Pakeman 2004) and conducted a PRC on this matrix. Log-transformed species data of 2001, 2002 and 2003 were used.

\section{Results}

\section{Biomass and grazing regime}

Grazing clearly had a significant effect on the standing live biomass, standing dead biomass, live/dead ratio and litter of the vegetation in the plots at the time of harvest. As expected the fully grazed plots had significantly less standing live biomass (5 to 35\% lower) than the ungrazed plots (Fig. 1a, b, Tables 2 and 3). However, no significant difference in biomass was found between the fully grazed and marmot-grazed plots (Table 3). Standing dead biomass was higher in the ungrazed than in the marmot-grazed (30 to 50\% higher) and the fully 

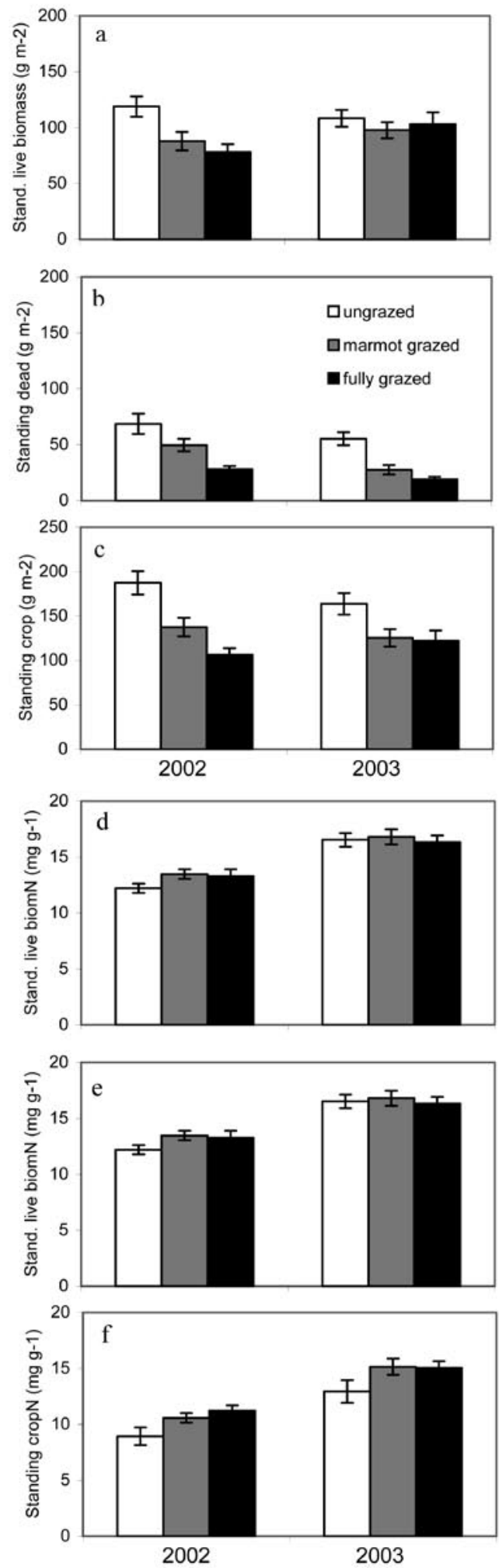

Fig. 1. Mean and standard error of (a) standing live biomass, (b) standing dead, (c) standing crop, the mean N-concentration in (d) standing live biomass, (e) standing dead and (f) standing crop of the vegetation of the ungrazed, marmot grazed and fully grazed treatment in 2002 and 2003.
Table 1. Mean and SE of root mass, root N-concentration and soil $\mathrm{N}$-concentration of the fully grazed, marmot grazed and ungrazed treatment in 2003. Means followed by a different letter within the same row are significantly different, as results from analysis of variance (One-way-ANOVA) with treatment as factor $(\mathrm{df}=2)(P<0.05)$.

\begin{tabular}{lccc}
\hline & Fully grazed & Marmot grazed & Ungrazed \\
\hline Roots $\left(\mathrm{g} / \mathrm{m}^{2}\right)$ & $548.1(68.2) \mathrm{a}$ & $475.1(37.3) \mathrm{a}$ & $555.5(67.0) \mathrm{a}$ \\
Root $\mathrm{Ng}(\mathrm{mg} / \mathrm{g})$ & $9.5(0.3) \mathrm{a}$ & $9.3(0.5) \mathrm{a}$ & $9.15(0.3) \mathrm{a}$ \\
Soil N $(\mathrm{mg} / \mathrm{g})$ & $2.47(0.0) \mathrm{a}$ & $2.49(0.1) \mathrm{a}$ & $2.53(0.1) \mathrm{a}$ \\
\hline
\end{tabular}

grazed plots (60 to $65 \%$ higher) (Fig. 1b, Table 3). Also a significant effect of grazing regime was found; the marmot-grazed plots had more standing dead material (30 to $40 \%$ higher) than the fully grazed plots.

In the dry year of 2002 the amount of standing dead material in all the plots was significantly higher than in the wet year 2003 (Fig. 1b, Table 2 and 3). From May till September in 2003 the precipitation was about three times more than in the same period in 2002 (see Methods). As a consequence of the stronger increase after reduced grazing in standing dead material than in standing live material, there was a significantly lower live/dead ratio of the standing crop (live and dead material) on the ungrazed plots (2.4 in 2002, 2.2 in 2003) than on the fully grazed plots (3.5 in 2002, 6.09 in 2003) (Fig. 1c, Table 3$)$. There was no significant difference in live/dead ratio between the fully grazed and marmot-grazed plots. No significant difference was found in the amount of

Table 2. $P$-values of a repeated measures (test of withinsubjects effects) with standing live biomass, standing dead, standing crop, live/dead ratio, litter, standing live biomass $\mathrm{N}$ concentration, standing dead N-concentration, standing crop N-concentration, Stipa frequency, Leymus frequency, Carex frequency, bunchgrass frequency and rhizomatous graminoids frequency as variables and year $(\mathrm{df}=1)$, grazing $(\mathrm{df}=2)$ and location ( $\mathrm{df}=3$ ) as factors, $\mathrm{df}=10$ for the error term. No significant interactions of grazing $\times$ location, year $\times$ grazing or year $x$ grazing $\times$ location for the variables were found, except for a significant interaction of year $\times$ grazing for Leymus frequency. * indicates significant effects at $p<0.05$.

\begin{tabular}{lllll}
\hline & Year & Year $\times$ loc & Grazing & Loc \\
\hline Standing live biomass & 0.259 & $0.003^{*}$ & $0.015^{*}$ & 0.316 \\
Standing dead & $0.003^{*}$ & 0.116 & $0.000^{*}$ & 0.101 \\
Standing crop & 0.437 & 0.054 & $0.000^{*}$ & 0.243 \\
Live/dead & $0.001^{*}$ & $0.002^{*}$ & $0.000^{*}$ & $0.037^{*}$ \\
Litter & 0.193 & $0.001^{*}$ & $0.016^{*}$ & $0.005^{*}$ \\
Standing live biomass N & $0.000^{*}$ & 0.162 & 0.383 & 0.121 \\
Standing dead N & $0.000^{*}$ & 0.368 & 0.237 & 0.225 \\
Standing crop N & $0.000^{*}$ & 0.395 & $0.010^{*}$ & $0.011^{*}$ \\
Stipa frequency & 0.837 & 0.845 & $0.028^{*}$ & $0.019^{*}$ \\
Leymus frequency & $0.001^{*}$ & 0.839 & $0.009^{*}$ & 0.651 \\
Carex freqeuncy & $0.000^{*}$ & 0.476 & 0.176 & 0.922 \\
Bunchgrass frequency & 0.253 & 0.828 & 0.477 & 0.090 \\
Rhizomatous gram. freq & $0.000^{*}$ & $0.010^{*}$ & $0.030^{*}$ & $0.022^{*}$ \\
\hline
\end{tabular}


litter between the ungrazed plots $\left(40.2\right.$ g.m $\mathrm{m}^{-2}$ in 2002 , $36.3 \mathrm{~g} . \mathrm{m}^{-2}$ in 2003) and the fully grazed $\left(31.9 \mathrm{~g} . \mathrm{m}^{-2}\right.$ in $2002,22.1$ g.m $\mathrm{m}^{-2}$ in 2003) or between the ungrazed and marmot-grazed plots $\left(37.1\right.$ g.m $\mathrm{m}^{-2}$ in $2002,33.2 \mathrm{~g} . \mathrm{m}^{-2}$ in 2003) (Table 3). There was only a significant difference between the fully grazed plots and marmot-grazed plots. Grazing did not have an effect on root biomass (Table 1).

\section{Nitrogen concentrations}

The N-concentrations of the standing live biomass, standing dead biomass and standing crop were significantly affected by year (Table 2). In the wet 2003 the N-concentrations were higher than in dry 2002 (Fig. 1d-f, Table 2, see Methods). Although there was no effect of grazing on the $\mathrm{N}$-concentrations of the standing live biomass (standing live $\mathrm{N}$ ) and the standing dead biomass (standing dead $\mathrm{N}$ ) separately, there was a significant grazing effect on the N-concentrations of the forage, being the standing crop (standing live and standing dead biomass, standing crop N) (Table 2). The fully grazed plots had significantly higher $\mathrm{N}$-concentrations of standing crop than the ungrazed plots (Fig. 1f, Table 3). Grazing did not affect root $\mathrm{N}$-concentrations and soil $\mathrm{N}$-concentrations (Table 1).

\section{Shift in species composition}

The frequency of the tussock grass Stipa krylovii in the plots was significantly affected by protection from grazing (Table 2). The higher frequency of Stipa in the ungrazed plots compared to the marmot-grazed plots was almost significant ( $p=0.057$ ) (Fig. 2a, Table 3). For the rhizomatous Leymus chinensis an interaction was found between year and grazing (Fig. 2b, Table 2) which means that the effect of grazing depended on the

Table 3. $P$-values of contrasts (repeated measures, tests of within-subjects contrasts) between the means per grazing treatment: Fully-, Marmot- and Ungrazed for 12 variables for the years 2002 and 2003 together. A Bonferroni correction was applied. * indicate significant effects $p<0.05$.

\begin{tabular}{lcccc}
\hline & $\begin{array}{c}\text { Fully } \\
\text { vs Marmot }\end{array}$ & $\begin{array}{c}\text { Fully } \\
\text { vs Un }\end{array}$ & $\begin{array}{c}\text { Marmot } \\
\text { vs Un }\end{array}$ & $\begin{array}{c}\text { Full +Marm } \\
\text { vs Un }\end{array}$ \\
\hline Standing live biomass & 0.711 & $0.006^{*}$ & 0.056 & $0.015^{*}$ \\
Standing dead & $0.007^{*}$ & $0.000^{*}$ & $0.000^{*}$ & $0.000^{*}$ \\
Standing crop & 0.132 & $0.000^{*}$ & $0.003^{*}$ & $0.000^{*}$ \\
Live/dead & 0.025 & $0.003^{*}$ & $0.013^{*}$ & $0.002^{*}$ \\
Litter & $0.009^{*}$ & 0.029 & 0.579 & 0.111 \\
Standing biomass N & 0.477 & 0.523 & 0.177 & 0.210 \\
Standing dead N & 0.716 & 0.212 & 0.111 & 0.094 \\
Standing crop N & 0.486 & $0.015^{*}$ & 0.032 & $0.015^{*}$ \\
Stipa frequency & 0.036 & 0.486 & 0.019 & 0.093 \\
Carex frequency & 0.848 & 0.122 & 0.063 & 0.036 \\
Bunchgrass frequency & 0.335 & 0.697 & 0.264 & 0.432 \\
Rhizomatous gram. freq. & 0.389 & 0.130 & $0.001^{*}$ & $0.003^{*}$ \\
\hline
\end{tabular}
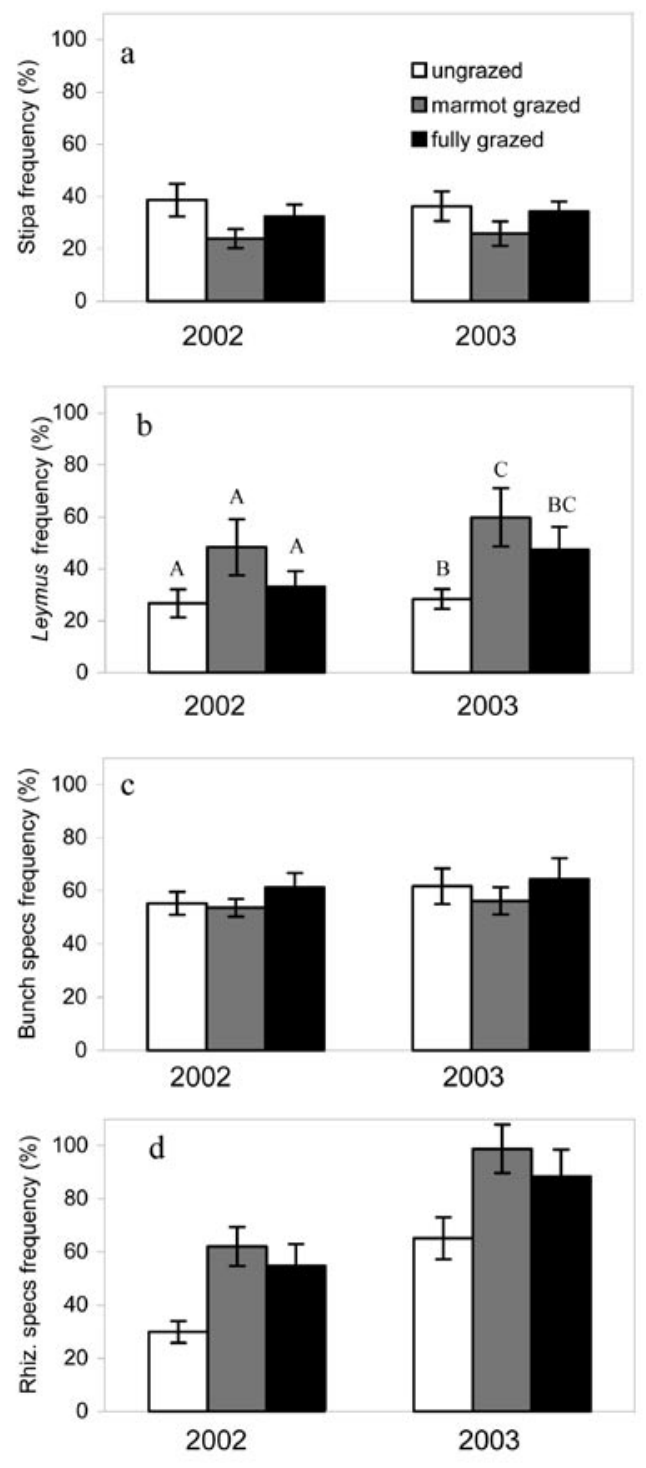

Fig. 2. Mean and SE of (a) Stipa frequency, (b) Leymus frequency, (c) bunchgrass frequency and (d) rhizomatous graminoids frequency of the vegetation of the ungrazed, marmot grazed and fully grazed treatment in 2002 and 2003. Different capitals above the bars in (b) indicate significant differences between the treatments within the year.

year. While in 2002 there was no effect of grazing, the frequency of Leymus in 2003 was lower in the ungrazed plots compared to the marmot-grazed plots (Fig. 2b). For Carex duriuscula, another rhizomatous species, there was no grazing effect on the frequency in the plots (Table 2). Yet there was an effect of year. In the wet summer of 2003 (see Methods) the frequency of Carex (54.3) was higher than in 2002 (29.2) (Table 2). The frequency of the group of tussock grasses (total of frequencies of tussock grass species) was not affected by grazing or any other factor (Fig. 2c, Table 2). 

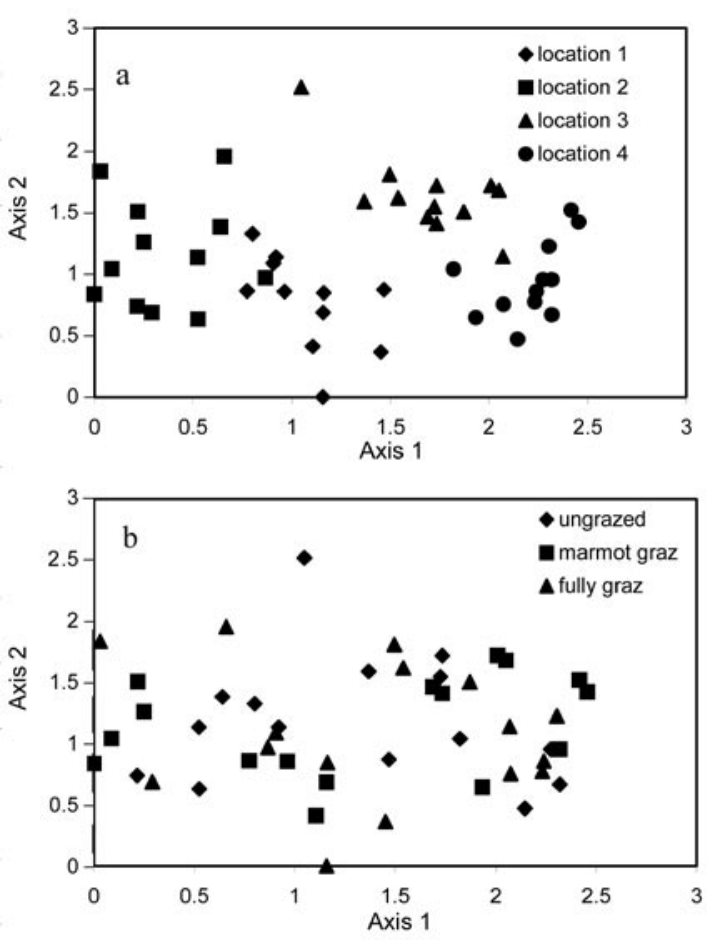

Fig. 3. Site scores (a) per location; (b) per treatment of a Detrended Correspondence Analysis (DCA) with species frequency data of 2003.

For the rhizomatous species group, there was a significant grazing effect on their frequency (total of frequencies of rhizomatous species) (Table 2) with a significantly higher frequency in the marmot-grazed plots than in the ungrazed plots (Fig. 2d, Table 3). They also had a higher frequency in the total of fully grazed and marmot-grazed plots than in the ungrazed plots.

After three years of exclusion the first two ordination axes of a Detrended Correspondence Analysis (DCA) of the species data (2003) are still completely determined by the differences between locations (Fig. 3a). For the site scores per grazing treatment however, no pattern was found (Fig. 3b). The Principle Response Curve analysis (PRC) of functional and sociological species groups showed that the highest response to treatment was shown by species characteristic of the Arctogeron subassociation and the moderate grazing facies, and by herbs (Fig. 4). These species increased in abundance when grazing was removed, but declined when grazing increased. A similar, but smaller, response was shown by species from the Galium verum subassociation and the tussock graminoids. Species characteristic of the severely grazed facies and from the rhizomatous graminoids showed the opposite behaviour. The scores of the cushion and shrub functional groups are close to zero, which means that they had not (yet) responded to the change in grazing regime.
Table 4. Means of tussock frequencies, basal area (BA) estimates and tiller densities of Stipa krylovii tussocks on fully grazed $(n=16)$ and ungrazed $(n=16)$ plots $(1 \mathrm{~m} \times 0.5 \mathrm{~m})$. \# With a $\chi^{2}$ test a significant grazing effect on the distribution of small and large tussocks within a plot was shown $(P<0.05)$. * Data were square-root transformed to perform an ANOVA. Means followed by a different letter within the same row are significantly different $(P<0.05)$.

\begin{tabular}{lcc}
\hline & Fully grazed & Ungrazed \\
\hline Tussock frequencies & & \\
Small tussocks $\left(\mathrm{BA}<25 \mathrm{~cm}^{2}\right)$ & $146^{\#}$ & $139^{\#}$ \\
Large tussocks $\left(\mathrm{BA}>25 \mathrm{~cm}^{2}\right)$ & $27^{\#}$ & $56^{\#}$ \\
Total tussocks & $173 \mathrm{a}$ & $195 \mathrm{a}$ \\
Basal areas & & \\
Basal area $\left(\mathrm{cm}^{2}\right) /$ tussock * & $12.12 \mathrm{a}$ & $19.46 \mathrm{~b}$ \\
Total basal area $\left(\mathrm{cm}^{2}\right) /$ plot* & $142.13 \mathrm{a}$ & $273.93 \mathrm{~b}$ \\
Tiller numbers and densities & & \\
Tillers / tussock & $40.82 \mathrm{a}$ & $52.76 \mathrm{a}$ \\
Tillers / $\left(\mathrm{cm}^{2}\right)$ BA & $5.13 \mathrm{a}$ & $6.19 \mathrm{a}$ \\
Tillers / plot* & $458.25 \mathrm{a}$ & $742.68 \mathrm{~b}$ \\
\hline
\end{tabular}

Tussock size and tiller density of Stipa krylovii

Grazing did not affect the total number of Stipa krylovii tussocks in the plots. Reduced grazing however, increased the proportion of large $\left(\mathrm{BA}>25 \mathrm{~cm}^{2}\right)$ and decreased the proportion of small tussocks $\left(\mathrm{BA}<25 \mathrm{~cm}^{2}\right)$ (Table 4). Individual tussock basal area and total basal area per plot were significantly increased by reduced grazing (Table 4). No significant effect of protection from grazing was found on the tiller density or on the number of tillers per tussock.

\section{Discussion}

The exclusion of large herbivores and small herbivores led to a higher plant standing crop in the plots. Grazing seemed to 'rejuvenate' the vegetation, as we found a much lower amount of standing dead material in the grazed plots than in the ungrazed plots. As a consequence, the live-dead ratio of the vegetation was much higher in the grazed plots. Also the forage quality was better under grazing. This seems solely to be the result of the higher live-dead ratio of the vegetation, as the standing live biomass had much higher $\mathrm{N}$-concentrations than the standing dead biomass, and $\mathrm{N}$-concentrations in either fraction were not affected by grazing. Nor did we find higher $\mathrm{N}$-concentrations in the roots or the soil under grazing. Contrary to the findings of Holland et al. (1992), who found an increased $\mathrm{N}$-mineralization and $\mathrm{N}$-availability leading to higher $\mathrm{N}$-concentrations in the standing live biomass, our results indicate that the better forage quality did not result from a higher $\mathrm{N}$-availability in this short-term experiment. Weather conditions, however, seemed to affect the $\mathrm{N}$-availability for the plants, 
Fig. 4. Principle response curve (log-transformed) indicating the effects of the ungrazed and marmot grazed treatments compared with the fully grazed treatment (scores on $\mathrm{x}$-axis) on functional and sociological species groups by sites. Attribute codes are: gram tus = tussock graminoids; gram rhi = rhizomatous graminoids; herb grf $=$ herbaceous growth forms; shrub grf = shrub growth forms; cushions = cushion growth forms; subass. $\mathrm{A}=$ Arctogeron subassociation; subass. $\mathrm{G}=$ Galium verum subassociation; facies $1=$ moderate grazing facies; facies 2 = severe grazing facies; assignment of species to sociological groups based on Hilbig (1995).

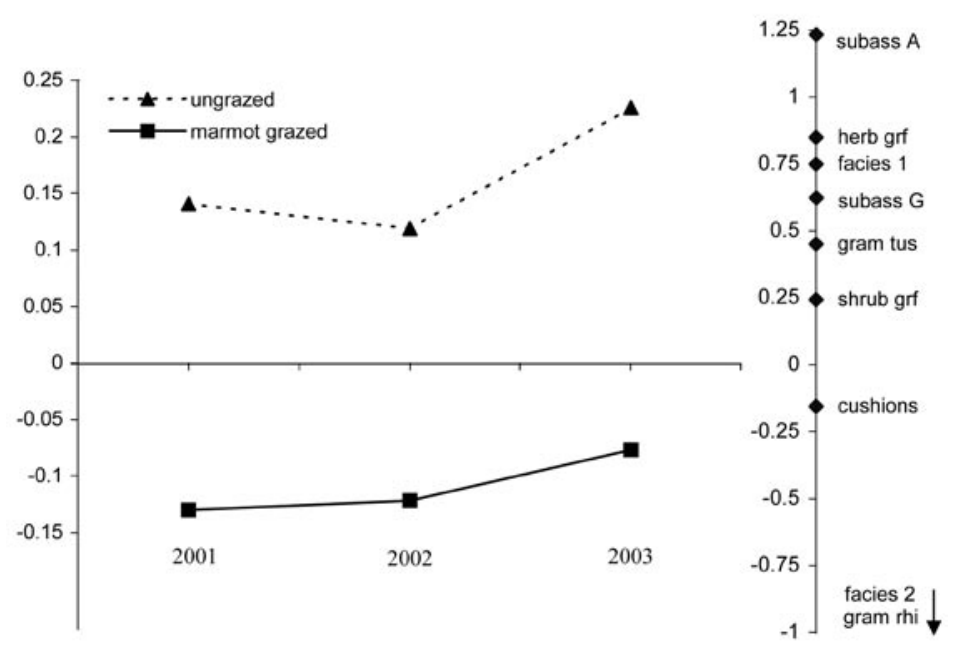

with higher $\mathrm{N}$-concentrations in the standing live and dead biomass in the wet year 2003. Presumably a higher moisture content of the soil resulted in an increased microbial activity, a higher N-mineralization and thereby a higher N-availability for the plants. 2003 was also one more year of succession and thus differentiation among treatments could have taken place, leading to the significant difference between the fully grazed and ungrazed treatment.

Although grazing was significantly lower under full grazing, root biomass was not affected. This is consistent with the results of Ferraro \& Oesterheld (2001) who analysed the responses of some 40 grass species to defoliation and reported a large negative effect on standing live biomass and just a minimal effect on root biomass. However, in a greenhouse experiment with Stipa and Leymus (van Staalduinen \& Anten 2005) a large defoliation effect on root biomass was found. Ferraro \& Oesterheld (2001) found that plants grown at high nitrogen levels were more negatively affected by clipping than plants at low nitrogen levels. Comparing the responses of individual plants (Ferraro \& Oesterheld 2001) with responses at ecosystem level (Oesterheld et al. 1999), the effects of defoliation on individual plants were much more negative. This can be explained by the fact that plants in pot experiments are often grown under high nitrogen levels, while plants in grazing ecosystems generally experience nitrogen limitation.

As was hypothesized, our results did show a lower frequency of the rhizomatous Leymus chinensis under reduced grazing, as well as a lower total frequency of rhizomatous species. This is in accordance with studies in North American prairies (Milchunas et al. 1988; Mack \& Thompson 1982), where high grazing pressure increased the rhizomatous species and decreased the tussock species. The increased frequency of Leymus and its higher grazing tolerance can be attributed to a much stronger compensatory growth in Leymus after defoliation than in Stipa, as was shown in a greenhouse experiment (van Staalduinen \& Anten 2005): higher compensatory growth in Leymus mainly resulted from a higher assimilation rate and the reallocation of stored carbohydrates from its rhizomes. In our exclosure experiment Leymus seemed to benefit more from grazing in the wet year of 2003 than in the dry year 2002, as its frequency increased more in the grazed plots in 2003 (Fig. 2b). For Stipa the frequencies remained the same in the two years. This is in accordance with van Staalduinen \& Anten (2005), who found that in Leymus there was more compensatory growth under wet than under dry conditions, while in Stipa compensation was decreased under wet conditions.

In our exclosures we found a marginally significant increase in the frequency of Stipa krylovii, but no increase in the frequency of all the tussock grasses after reduced grazing. However, we found extended basal areas, higher tiller densities and a shift to taller tussocks of Stipa (Table 4), which ultimately will lead to an increase of the Stipa population. Butler \& Briske (1988) reported similar results in their study on the population structure of the tussock grass Schizachyrium scoparium.

Large parts of the steppes of Mongolia and Central Asia currently suffer from overgrazing due to the enormous increase in the number of livestock during the last decades. Overgrazing has led to a decrease in vegetation cover, productivity and plant species diversity, and a replacement of the original dominant Stipa grasses by species such as Leymus chinensis and Carex duriuscula. Our results show that a reduction in grazing pressure can promote a change in the ratio of rhizomatous to tussock grasses in the vegetation, which might help restore the original Stipa steppe. 
Acknowledgements. MAvS gratefully acknowledges financial support for this study by the Foundation for the Preservation and Protection of the Przewalski Horse (FPPPH), the Hugo de Vries Fonds and the Schure-Beijerinck-Popping Fonds. She thanks the biologists Bulgan Ayush, Munkhbat and Ariunzaya and the students Bayaraa, Otga and many others for their help with the field measurements, Jan Bakker for his advice on the set up of the experiment and Paul Westers for his advice on statistics. She sincerely thanks the Hustai National Park for providing facilities and accommodation during the fieldwork.

\section{References}

Anon. 1998-2001. Inventories and monitoring at Hustain Nuruu National Park. Takhi Reintroduction Centre, Mongolian Association for Conservation of Nature and the Environment. Internal Report. Ulaanbaatar, MG.

Anon. 2000-2002. Meteorological survey of Mongolia. Internal Report, Hustai National Park, Ulaanbaatar, MG.

Anon. 2003. Climate view of Hustai National Park in 2003. Internal Report, Hustai National Park, Ulaanbaatar, MG.

Anten, N.P.R, Martinez-Ramos, M. \& Ackerly, D.D. 2003. Defoliation and growth in an understory palm: quantifying the contributions of compensatory responses. Ecology 84: 2905-2918.

Bakker, J.P., De Leeuw, J. \& van Wieren, S.E. 1983. Micropatterns in grassland vegetation created and sustained by sheep-grazing. Vegetatio 55: 153-161.

Butler, J.L. \& Briske, D.D. 1988. Population structure and tiller demography of the bunchgrass Schizachyrium scoparium in response to herbivory. Oikos 51: 306-312.

Detling, J.K. 1998. Mammalian herbivores: ecosystem-level effects in two grassland national parks. Wildl. Soc. Bull. 26: 438-448.

Fernandez-Gimenez, M. \& Allen-Diaz, B. 2001. Vegetation change along gradients from water sources in three grazed Mongolian ecosystems. Plant Ecol. 157: 101-118.

Ferraro, D.O. \& Oesterheld, M. 2002. Effect of defoliation on grass growth. A quantitative review. Oikos 98: 125-133.

Grubov, V.I. 2001. Key to the vascular plants of Mongolia. Science Publishers, Enfield, NH, US.

Gunin, P.D., Vostokova, E.A., Dorofeyuk, P.E., Tarasov, P.E. \& Black, C.C. (eds.) 1999. Analysis of present-day vegetation dynamics. In: Vegetation dynamics of Mongolia, pp. 131164. Kluwer Academic Publishing, Boston, MA, US.

Hilbig, W. 1995. The vegetation of Mongolia. SPB Academic Publishers, Amsterdam, NL.

Holland, E.A., Parton, W.J., Detling, J.K. \& Coppock, D.L. 1992. Physiological responses of plant populations to herbivory and their consequences for ecosystem nutrient flow. Am. Nat. 140: 685-706.

Jongman, R.G.H., ter Braak, C.J.F. \& van Tongeren, O.F.R. 1995. Data analysis in community and landscape ecology. Cambridge University Press, Cambridge, UK.

Mack, R.N. \& Thompson, J.N. 1982. Evolution in steppe with few large, hooved mammals. Am. Nat. 119: 757-77.

Milchunas, D.G., Sala, O.E. \& Lauenroth, W.K. 1988. A generalized model of the effects of grazing by large herbivores on grassland community structure. Am. Nat. 132: 87-106.

Oesterheld, M. 1992. Effect of defoliation intensity on aboveground and belowground relative growth rates. Oecologia 92: 313-316.

Oesterheld, M., Loreti, J., Semmartin, M. \& Paruelo, J.M. 1999. Grazing, fire and climate as disturbances of grasslands and savanna. In: Walker, L. (ed.) Ecosystems of disturbed ground, pp. 303-322. Elsevier, Amsterdam, NL.

Olff, H. \& Ritchie, M. 1998. Effects of herbivores on grassland plant diversity. Trends Ecol. Evol. 13: 261-265.

Pakeman, R.J. 2004. Consistency of plant species and trait responses to grazing along a productivity gradient: a multisite analysis. J. Ecol. 92: 893-905.

ter Braak, C.J.F. \& Šmilauer, P. 2002. CANOCO Reference manual and CanoDraw for Windows User's Guide: software for canonical community ordination, version 4.5. Micro-computer Power, Ithaca, NY, US.

van Staalduinen, M.A. 2005. The impact of herbivores in a Mongolian forest steppe. Ph.D. Thesis, Utrecht University, Utrecht, NL.

van Staalduinen, M.A. \& Anten, N.P.R. 2005. Difference in the capacity for compensatory growth of two co-occurring grass species in relation to water availability. Oecologia 146: 190-199.

Wallis de Vries, M.F., Manibazar, N. \& Dugerlham, S. 1996. The vegetation of the forest-steppe region of Hustain Nuruu, Mongolia. Vegetatio 122: 111-127.

Wang, Z., Li, L., Han, X. \& Dong, M. 2004. Do rhizome severing and shoot defoliation affect clonal growth of Leymus chinensis at ramet population level? Acta Oecol. 26: 255-260.

Werger, M.J.A., Hirose, T., During, H.J., Heil, G.W., Hikosaka, K., Ito,T., Nachinshonhor, U.G., Nagamatsu, D., Shibasaki, K., Takatsuki, S., van Rheenen, J.W. \& Anten, N.P.R. 2002. Light partitioning among species and species replacement in early successional grasslands. J. Veg. Sci. 13: 615-626.

Xie, Y. \& Wittig, R. 2003. Growth parameters of characteristic species of Stipa steppes in Northern China as indicators of the grazing intensity. J. Appl. Bot. 77: 68-74.

Received 20 July 2005; Accepted 14 August 2006; Co-ordinating Editor: R.J. Pakeman. 